\title{
Determining breeding knowledge, goals and practices of Lithuanian dog breeders
}

Vykintas Baublys*,

Vaida Tubelytė

Vytautas Magnus University,

Department of Biology,

Vileikos 8, LT-3035 Kaunas,

Lithuania
Questionnaires are a useful method to determine breeder's selection strategies, knowledge, and dog breeds welfare, as well as to define the current situation. Evaluation of the situation can lead to changes in breeding policies. The aim of our work was to study the differences that could exist among dog breeders concerning their opinions and practices when dealing with breeding goals, selection tools, livestock management and reproduction methods. To achieve that, we sought to determine a breeder's knowledge and their sources of information, breeding tendencies, breeders' view on genetic testing methods and their motivation for breeding goals. This investigation was based on anonymous questionnaire analysis. After summarizing data, it emerged that, in general, there is a lack of information about breeding in public information sources. Majority of the Lithuanian breeders (83.7\%) indicated that their breeding goal was to improve breed exterior, character and health. To achieve these goals, breeders more often choose a line-breeding strategy than the close breeding one $(30.2 \%$ and $11.6 \%$, respectively). Majority of the respondents recognized the importance of genetic testing in dog breeding.

Key words: breeders, breeding goals, dogs, survey

\section{INTRODUCTION}

The Lithuanian Cynological Society (LCS) unites 44 Lithuanian dog clubs. In 2009, there were registered about 750 litters and about 3700 pedigrees (www.kinologija.lt). Most litters in Lithuania come from occasional breeders, who register a litter from time to time and there are few professional breeders as well. There is a lack of information about the breeding management methods for Lithuanian breeders to use.

When animals are bred by a person on purpose, the aim should be to meet certain goals: to improve the precision with which breeding outcomes can be predicted; to avoid the introduction and advance of characteristics, deleterious to well-being; and to manage genetic resources and diversity between and within the populations [1]. Questionnaires are a useful method to determine the breeder's selection strategies, knowledge, and dog breeds welfare, as well as to

* Corresponding author. E-mail: v.baublys@gmf.vdu.lt define the current situation. Evaluation of the situation can bring changes in breeding policies. Some publications reveal problems and suggest solutions for breeding and owning policies.

Yuying Hsu and colleagues [2] showed that a questionnaire may be useful in screening dogs for behavior problems and in evaluating the clinical effects of various treatments. There are some investigations of canine aggression and determination related to the owner's education $[3,4]$. Many works are carried out to determine the health status of purebred dogs and to give solutions for the breeders and owners how to solve these problems [5-9]. Many new DNA-based tests for analysis of genetic diseases and traits (e. g. coat colour) are now available for use by both, breeders and veterinarians. With an appropriate interpretation, these tests can be used as invaluable tools in a breeding programme. Selection strategies that do not take into account maintaining the genetic diversity of the breed may be detrimental and reduce the potential for future improvement [10]. A variety of genetic methods is used to determine 
different traits: single nucleotide polymorphism (SNP) analysis [11,12], microsatellite analysis [13], mitochondrial DNA [14], gene candidate search [15] and analysis of pedigree records [16-18].

The aim of our work was to study the differences that could exist among dog breeders in their opinions and practices dealing with breeding goals, selection tools, livestock management and methods of reproduction. To achieve that, we sought to determine breeders' knowledge and their sources of information; breeding tendencies, breeders' view on genetic testing methods and their motivation for breeding goals.

\section{MATERIAL AND METHODS}

The questionnaire was anonymous and composed of 20 questions. It was distributed by Internet survey mechanism (in the questionnaire web site www.manoapklausa.lt) and dealt with such subjects as information of breeders' experience, their knowledge and information sources of breeding information, selection, reproduction and opinion about genetic testing. Answering the questions, the respondents were asked to give a number, to check one or several boxes, or to grade the best answers within the list of choices.

The time limit for returning the questionnaire was fixed to 1 month in spring 2009. The total number of received answers was 43. A copy of the questionnaire, written in Lithuanian, is available on demand.

Breeders were differentiated into three groups. In this paper, we focus on the main three categories: the breeder's experience (time of breeding practice), the number of litters and breeder's education (whether they have higher biological / veterinary / husbandry education or not).

A lot of dog owners think about a possibility of becoming a breeder. Sometimes it happens because they see all the best breed traits in their dogs, sometimes because they think they have a sufficient knowledge background, sometimes because they think that it is a good and enjoyable job. Usually they overestimate their knowledge, competence and reasons for breeding. After the breeding practice, novice breeders realize the truth and quit breeding. However, some of them continue breeding and gaining new experiences and knowledge, while others work without any programme for the breed's welfare and excellence. Thus, we think it is a reasonable criterion to distinguish different types of breeders. According to their experience, the breeders were separated into three groups: "Beginners", with the breeding experience of no longer than 5 years; "Experienced breeders", the breeding experience ranged from 5 to 15 years and "Old-stagers", who had breeding experience longer than 15 years (Table 1 ).

The number of litters produced is an indicator of the kennel size and is one of the factors revealing the breeders' income [19], besides it can demonstrate their attitude to breeding. Between the respondents, there were no breeders producing more than 4 litters per year. In Lithuania, only few breeders can make money from breeding and the majority of kennels is not big. Thus, the questionnaire does not reflect the professional breeders' opinion. However, it shows the opinion of the most numbered group of Lithuanian breeders (non-professionals), who are in need of breeding information. Breeders were separated according to the number of litters per year into two groups: "Hobby breeders", who had not more than 2 litters per year, and "Regular breeders" who had from 2 to 4 litters per year (Table 1).

Higher education in Nature sciences provides additional knowledge and skills for dog breeders. It was particularly appealing to assess if there was any difference between the breeders with the education in biology, veterinary or husbandry and the ones without it. The first group (with higher education in Natural sciences) was called "Specialists" and, with all our respect and apologies, for purely practical reasons, the others were called "Non-specialists" (Table 1). All analyses were performed using SPSS v.13.0 software (SPSS, Chicago, IL).

\section{RESULTS AND DISCUSSION}

We evaluated the breeders' opinion on the abundance and accessibility of useful public information for breeding dogs. Half of the respondents (53.5\%) indicated that there was a lack of information about breeding in public information sources (Fig. 1). Most of all, about the lack of information, complained the old-stagers (66.7\%). The beginners had the most favourable attitude $-25 \%$ indicated that there was plenty of information about breeding. The old-stager breeders faced more complicated problems and noticed a lack of specialized information. Also, it could have been due to the Internet mining capability - the younger people use the Internet better than older people. The majority of information, found in the World Wide Web (www), is in English. Some of the old-stagers do not use the Internet at all and have difficulties with the English language. However, a more detailed analysis has to be done to reject or accept this hypothesis.

Table 1. Breeder groups according to different criterion and the percentage of respondents in every group

\begin{tabular}{|c|c|c|c|c|c|c|}
\hline \multicolumn{3}{|c|}{ By experience } & \multicolumn{2}{|c|}{ By number of litters } & \multicolumn{2}{|c|}{ By education } \\
\hline Beginners & Experienced breeders & Old-stagers & Hobby breeders & Regular breeders & Specialists & Non-specialists \\
\hline $46.5 \%$ & $39.5 \%$ & $14 \%$ & $83.7 \%$ & $16.3 \%$ & $34.9 \%$ & $65.1 \%$ \\
\hline
\end{tabular}




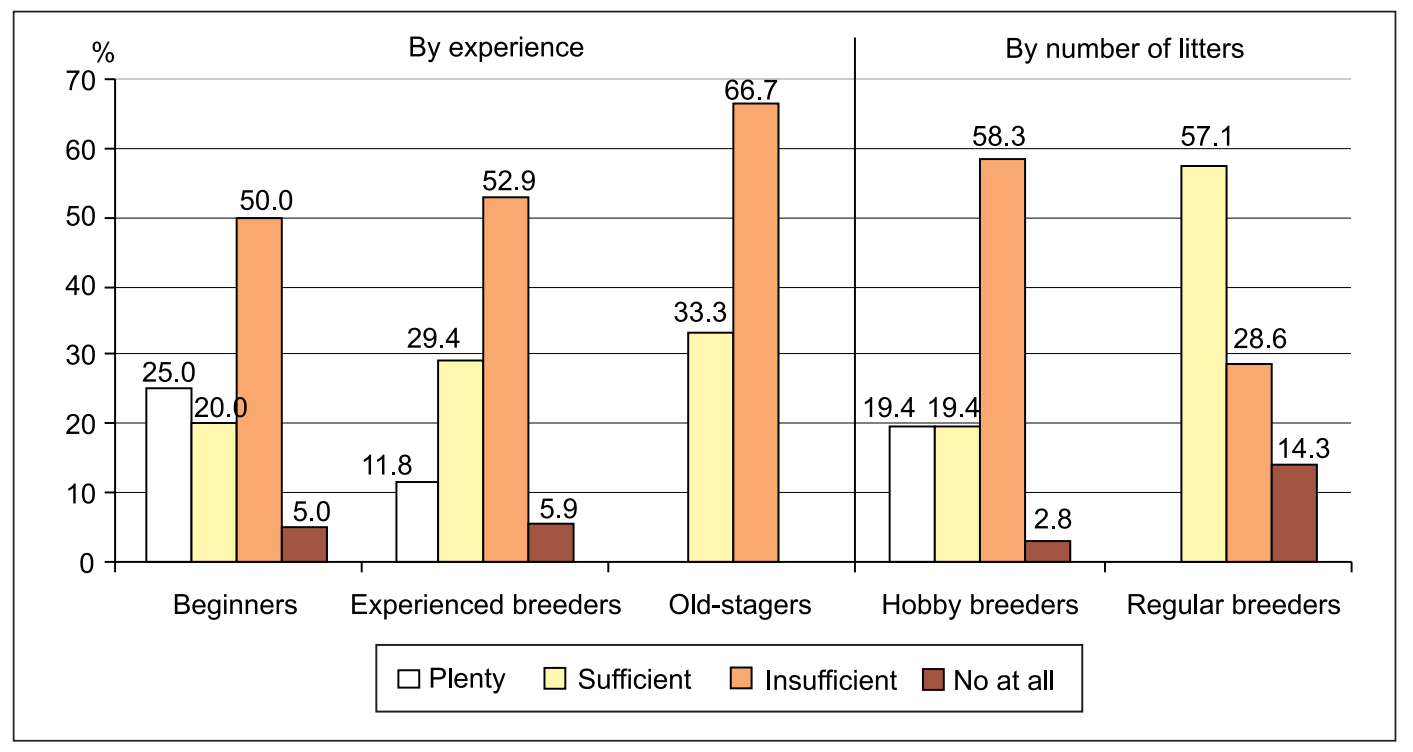

Fig. 1. Breeders' opinion about abundance and accessibility of public information useful for dog breeding

People with higher education in Natural Sciences could more easily find specific information for breeders. However, the results of our questionnaire showed no difference between the answers of specialists and non-specialists: respectively, $46.7 \%$ and $57.1 \%$ of respondents indicated the lack of information.

Significant differences were detected between the hobby and regular breeders: $58.3 \%$ of the hobby breeders indicated the lack of information, while only $28.6 \%$ of the regular breeders complained about it (Fig. 1). Respectively, $57.1 \%$ of regular breeders found the public information about breeding to be sufficient and only $19.4 \%$ of hobby breeders were that optimistic on this question. It could be that regular breeders spent more time in search for information.

The breeders also answered the question concerning the source of information about breeding. When answering this question, a respondent might have indicated multiple answers: "from personal practice"; "improved in specialized seminars, courses or literature"; "from communication with other breeders"; "not much particular knowledge, breeding is guided by intuition and grades in dog shows". After summarizing all data, it emerged that, in general, the breeders got information from specialized seminars, courses or literature (48.8\%) and from communication with other breeders (51.2\%). As was expected, the beginners ( $95 \%$ of them) did not appeal to their experience in breeding. In a way, it is promising, because it indicates the level of their knowledge and a lack of breeding practice. However, the experienced breeders and the old-stagers feel more certain about their breeding practice. About $50 \%$ of the breeders in these groups indicated personal practice as the priority to the information source for breeding. The old-stagers (66.7\%) indicated, "commu- nication with other breeders", as the priority for gathering information about breeding. That means that communication and information sharing between veteran breeders is extremely popular and appreciated. Such a likeable communication can occur because breeding business is not well paying in Lithuania, as a part of the breeders indicated in their answers. Thus, the breeders must earn money in other jobs, and they do not have time to attend any specialized courses, but just share the information between themselves. Such way of communication can lead to the spread of incorrect information among breeders. The breeders with higher education in Natural sciences, as expected, seek information mainly in specialized seminars, courses or literature. The non-specialists prefer to communicate with other breeders. Similar situation was detected between the regular breeders and the hobby ones. The regular breeders choose a specialized help while the hobby breeders give priority to communication.

In the questionnaire, the breeders were asked to if they are interested in dogs' genetic studies and to indicate their knowledge level in this field. Up to now, genetic testing is not obligatory in Lithuania. However, if the breeder wishes, he can do a parentage testing. Other tests like coat colour, genetic diseases and breed determination could be done only by sending samples to foreign laboratories (e. g., available tests on http://www.vetmed.lt/). From all the respondents only one breeder indicated that had done genetic tests for his dogs. To the question "Do you know about genetic tests (coat colour, genetic disease, parentage, and breed identification)?", 67.4\% answered "Yes, I'm interested in it"; $18.6 \%$ answered "Yes, I have heard something"; $14 \%$ answered "I haven't heard about it, but I would like to know". There was another answer to this question "Don't know and don't want to know", but nobody indicated it. From these 
results we see that a significant part of the breeders doesn't know about the genetic tests. After data analysis, it was detected that the majority of the breeders, unaware of genetic tests (25\%), belonged to the beginners group. The biggest part of the breeders, who knew and were interested in the genetic tests, was found in the old-stagers group (83.3\%) and in the specialists group (80\%). Surprisingly, the smallest number of interested in genetic tests breeders was found in the regular breeders group (57.1\%). It looks like a half of them do not bother themselves with the information which is not essential according to LCS dog breeding rules (www. kinologija.lt).

In the other part of the questionnaire, we evaluated breeding goals and programmes of the Lithuanian dog breeders. To the question "Why are you breeding dogs?", only one breeder indicated, that it is his business. To this question, the respondents could select multiple answers. The majority (83.7\%) of the breeders indicated that their breeding goal was to "improve breed exterior, character and health". It shows the intentions of Lithuanian breeders' to be more for hobby reasons, than for business. On 7\% of questionnaires, a written postscript was found stating that breeding is a loss-making activity. This statement confirms our conclusion about Lithuanian breeders' intentions. A part of respondents (13.9\%) indicated that they became breeders, because they wanted to pass their own pet's best traits to future generations. This breeding policy was not detected only in the old-stagers group: all members of this group considered the breeding in the most professional way - "improve breed exterior, character and health".

Using the questionnaire, we wanted to find out how the breeders communicate with each other and how they share reproducers to form pairs. It was detected that for reproduction the Lithuanian breeders (76.7\%) usually take reproducers from a foreign country kennel to form couples. The old-stagers and the regular breeders use exclusively foreign reproducers. The variety of foreign countries is very great, from our neighbour countries to the USA. However, the European Union countries dominate, especially the Baltic Sea countries. Moreover, quite a lot of the Lithuanian breeders are bringing reproducers from the post-soviet countries. Such a variety of cooperation is very promising; it decreases inbreeding and increases genetic variability, which greatly contributes to the welfare. Very few breeders ( $4.7 \%$ ) indicate that they take reproducers only from their own kennel. It could be explained by the lack of knowledge in breeding as all these breeders were non-specialists.

We also determined by which criterions breeders choose reproducers for mating (Table 2). The primary priorities for mating were health and genealogy. Our investigation data show that breeders disregard a dog show awards. Otherwise, show awards have a large influence on the selection of dogs, used in breeding. Breeders did not indicate the character as the priority criterion for mating. It could be because of the difficulty to determine it, and in some shows the dog's, character is not a criterion for an award at all.

From Table 2, we can see that the regular breeders stand out of all other groups. They trust most of all show awards or think that it is the best criterion for selling dogs. The regular breeders also indicated that character is the least important criterion for mating. It is strange that the old-stagers and the regular breeders neglected the health criterion and indicated that the exterior was a more worthy trait.

Two questions were presented in the questionnaire to evaluate the practice of line-breeding and close-breeding, respectively. Line-breeding was defined as the mating of a sire and a dam sharing the same far ancestor, present several times in their pedigree, and close-breeding as mating of closely related dogs, e. g., half or full sibs. We detected that $11.6 \%$ of the respondents were using close-breeding. It is forbidden by the LCS dog breeding rules, except if a breeder gets the permission from the LCS breeding commission. Line-breeding was used by $30.2 \%$ of the respondents. We compared these results with the ones of Leroy and colleagues from France [19]. The comparison revealed that in France close-breeding and line-breeding were used more frequently ( $24 \%$ and $49 \%$, respectively). Between the questionnaire respondents, the line-breeding was used more frequently by the experienced breeders, the old-stagers and the regular breeders $(41.2 \%, 50 \%$ and $42.9 \%$, respectively). The beginners used the line-breeding seldom (15\%) and did not use the close-breeding at all. Close-breeding was quite frequent in the old-stagers group (33.3\%). The ma-

Ta ble 2. Average rank of reproducers for mating criterions, declared by the breeders overall $(a)$ and according to the group $(b)$. The lower number being the best goal, there was no significant effect of breeder's education on the answers

\begin{tabular}{c|c|c|c|c|c|c}
\hline \multirow{2}{*}{ Mating criterions } & All breeders & \multicolumn{4}{c}{ Breeder groups } \\
\cline { 3 - 7 } & & Beginners & $\begin{array}{c}\text { Experienced } \\
\text { breeders }\end{array}$ & Old-stagers & $\begin{array}{c}\text { Hobby } \\
\text { breeders }\end{array}$ & $\begin{array}{c}\text { Regular } \\
\text { breeders }\end{array}$ \\
\hline Dog show awards & $\mathbf{4 . 2 3}$ & 4.05 & 4.41 & 4.33 & $\mathbf{3 . 0 0}$ \\
\hline Exterior & 2.81 & 2.90 & 3.00 & $\mathbf{2 . 0 0}$ & 2.89 \\
\hline Character & $\mathbf{3 . 7 0}$ & 3.85 & 3.65 & 3.33 & $\mathbf{2 . 4 3}$ \\
\hline Health & $\mathbf{1 . 9 5}$ & $\mathbf{1 . 8 0}$ & $\mathbf{1 . 7 6}$ & $\mathbf{3 . 0 0}$ & $\mathbf{1 . 7 5}$ \\
\hline Genealogy & 2.30 & 2.18 & 2.18 & $\mathbf{2 . 3 3}$ & $\mathbf{3 . 0 0}$ \\
\hline
\end{tabular}


a

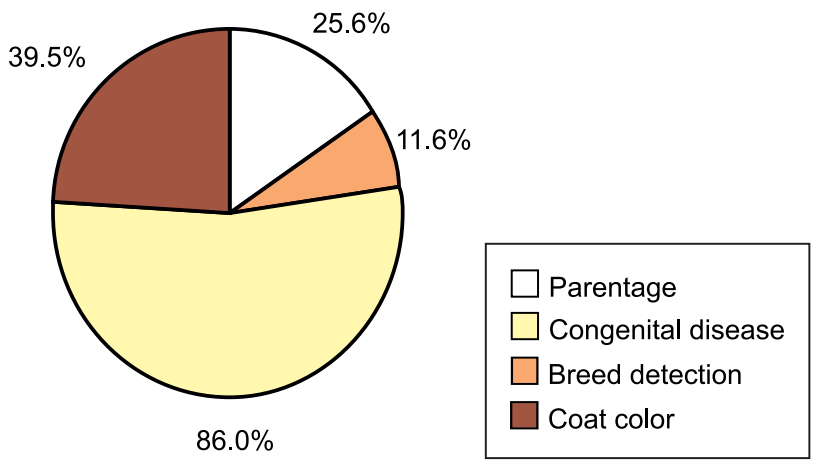

$b$

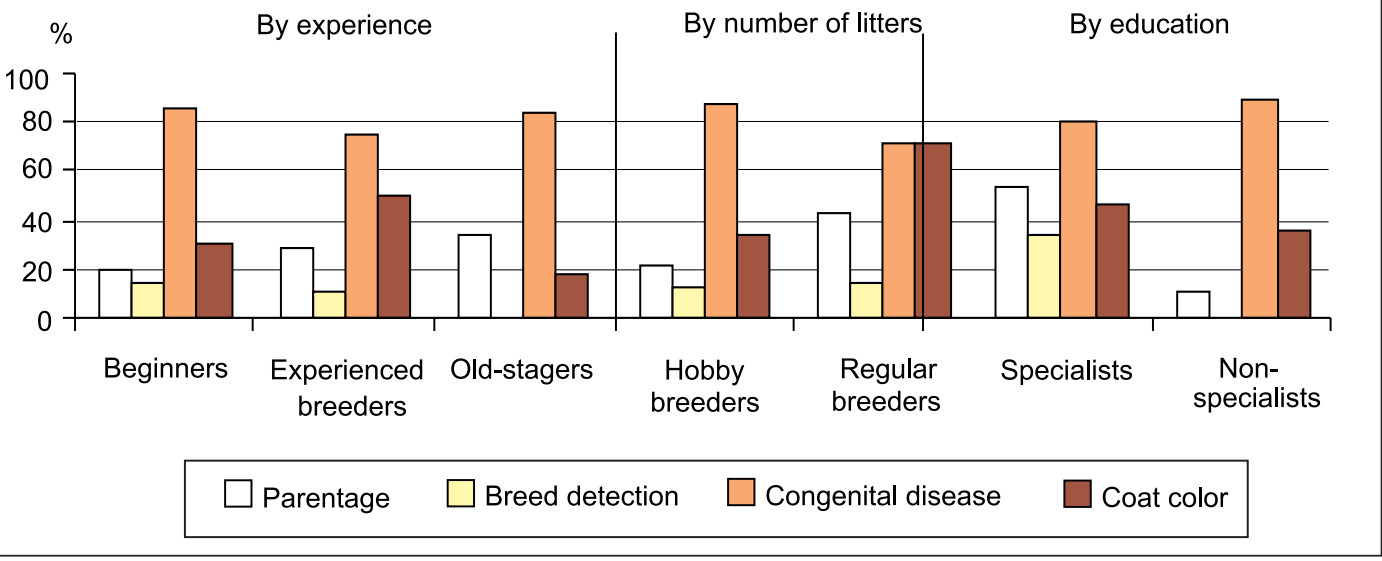

Fig. 2. Breeders' opinion about the most useful genetic tests.

The percentage shows the number of the breeders who indicated the test as useful

jority of the respondents to the question "Why did you use the pedigree breeding?", - answered that they wanted to fix positive parental traits.

The Lithuanian breeders indicated quite a good quality of their litters. Almost a half (48.8\%) of breeders indicated that there were no litters in their kennel with defected puppies and 39.5\% indicated what there were no litters in their kennel with dead puppies. The old-stagers, due to their long lasting experience, declared that puppies with defects were born very rarely.

As mentioned earlier, genetic tests are a new practice in Lithuania. Only one of all respondents answered that had used genetic testing methods. A big part of breeders (62.8\%) would like to do genetic tests in Lithuania. $16.3 \%$ of the respondents indicated that the cost of tests is a very important criterion. As genetic tests are not obligatory, breeders use other (classical) methods to find good reproducers. Nevertheless, they understand that genetic testing gives more advanced information, as $81.4 \%$ of the respondents revealed that when choosing reproducers from foreign countries the genetic certificate was very important to them.
One of the questions asked was, which of the genetic tests are most useful for breeders (Fig. 2). To this question the respondents could select multiple answers: "parentage test", "breed detection test", "congenital disease test" and "coat colour test". The questionnaire analysis showed that the breeders were mostly interested in congenital diseases tests. Coat colour tests were treated differently: only $16.7 \%$ of the old-stagers, but even $71.4 \%$ of the regular breeders expressed their interest. The need of testing coat colour genes may depend on the dog breed. The owners of the kennel bred dogs with one determined coat colour (e. g. Argentinean mastiff) had no interest for this test. However, because of a small number of respondents and dog breed varieties in their kennels, the dog breeds were not considered. The parentage test took the third place. Breed identification in the hybrids test didn't engage breeders at all. We have noticed the tendency of the younger breeders (with less experience) to be interested in a bigger variety of genetic tests. The old-stagers have already got their fixed point of view about the usefulness of different genetic tests. 


\section{CONCLUSIONS}

After summarizing the data, it emerged that, in general, breeders got information from specialized seminars, courses or literature as well as from communication with each other. A half of the respondents indicated that there was a lack of information about breeding in public information sources. Thus, there is a need of specialized free courses for the breeders to improve their knowledge. Majority of the Lithuanian breeders indicated that their breeding goal was to "improve breed exterior, character and health". For the purpose to fix positive parental traits, the Lithuanian breeders more frequently chose a line-breeding in comparison with close breeding. Quite a lot of Lithuanian breeders are bringing reproducers from foreign countries. Cooperation with foreign breeders is very promising; it is decreasing inbreeding and increasing genetic variability, which greatly contributes to the welfare of puppies. We have also determined the criterions by which breeders choose the reproducers for mating. The primary priorities for mating were health and genealogy. Majority of the respondents indicated that when choosing reproducers from foreign countries, the genetic certificate was very important to them. If genetic tests were done in Lithuania, then the majority of breeders would like to test their kennel reproducers. Of course, it depends on the test price. From all genetic tests, which the breeders would like to do in Lithuania, the most popular is the congenital disease test. We have also noticed the tendency of the younger breeders (with less experience) to be interested in a bigger variety of genetic tests. The oldstagers have already got their fixed point of view about the usefulness of different genetic tests.

\section{ACKNOWLEDGEMENTS}

We are very grateful to Mrs J. Jazdauskaite for her help during questionnaire distribution.

Received 17 March 2011 Accepted 30 May 2011

\section{References}

1. Flint APF, Woolliams JA. Precision animal breeding. Phil Trans R Soc B 2008; 363: 573-90.

2. Hsu Y, Serpell JA. Development and validation of a questionnaire for measuring behavior and temperament traits in pet dogs. J Am Vet Med Assoc 2003; 223: 1293-300.

3. Berg L, Schilder MBH, Knol BW. Behavior Genetics of Canine Aggression: Behavioral Phenotyping of Golden Retrievers by Means of an Aggression Test. Behav Genet 2003; 33(5): 469-83.
4. Berg L, Schilder MBH, Vries H, Leegwater PAJ, Oost BA. Phenotyping of Aggressive Behavior in Golden Retriever Dogs with a Questionnaire. Behav Genet 2006; 36: 882-902.

5. Adams VJ, Evans KM, Sampson J, Wood JL. Methods and mortality results of a health survey of purebred dogs in the UK. J Small Anim Pract 2010; 51(10): 512-24.

6. Wandeler AI. The rabies situation in Western Europe. Dev Biol (Basel) 2008; 131: 19-25.

7. Courcier EA, Thomson RM, Mellor DJ, Yam PS. An epidemiological study of environmental factors associated with canine obesity. J Small Anim Pract 2010; 51(7): 362-7.

8. Bland IM, Guthrie-Jones A, Taylor RD. Dog obesity: veterinary practices' and owners' opinions on cause and management. Hill J. Prev Vet Med 2010; 94(3-4): $310-5$.

9. McGreevy PD. Sick as a dog: outraged by the health problems pedigree dogs suffer, Paul McGreevy argues that it's high time dog breeders threw away the rule book. New Sci 2008; 200(2677): 18.

10. Traas AM, Casal M, Haskins M, Henthorn P. Theriogenology 2006; 66: 599-605.

11. Chang ML, Yokoyama JS, Branson N, Dyer DJ, Hitte C, Overall KL, Hamilton SP. Intrabreed Stratification related to divergent selection regimes in purebred dogs may affect the interpretation of genetic association studies. J Hered 2009; 100 (suppl 1): S28-36.

12. Boyko AR, Quignon P, Li L et al. A simple genetic architecture underlies morphological variation in dogs. PLoS Biol 2010; 8(8): e1000451.

13. Björnerfeldt S, Hailer F, Nord M., Vilà C. Assortative mating and fragmentation within dog breeds. BMC Evol Biol 2008; 8: 28.

14. Van Asch B, Pereira L, Pereira F, Santa-Rita P, Lima M, Amorim A. MtDNA diversity among four Portuguese autochthonous dog breeds: a fine-scale characterisation. BMC Genet 2005; 6: 37.

15. Aguirre-Hernández J, Sargan DR. Evaluation of candidate genes in the absence of positional information: a poor bet on a blind dog! J Hered 2005; 96(5): 475-84.

16. Calboli FCF, Sampson J, Fretwell N, Balding DJ. Population Structure and Inbreeding from Pedigree Analysis of Purebred Dogs. Genetics 2008; 179: 593-601.

17. Glazewska I. Genetic diversity in Polish hounds estimated by pedigree analysis. Livest Sci 2008; 113: 296-301.

18. Leroy G, Rognon X, Varlet A, Joffrin C, Verrier E. Genetic variability in French dog breeds assessed by pedigree data. J Anim Breed Genet 2006; 123: 1-9.

19. Leroy G, Verrier E, Wisner-Bourgeois C, Rognon X. Breeding goals and breeding practices of French dog breeders: results from a large survey. Revue Med Vet 2007; 158(10): 496-503. 
Vykintas Baublys, Vaida Tubelytė

\section{LIETUVOS ŠUNŲ VEISĖJŲ ŽINIOS, VEISIMO TIKSLAI \\ IR METODIKOS}

\section{Santrauka}

Apklausos anketos yra naudingas metodas ịvertinant šunų veisèjų žinias, naudojamas veisimo strategijas ir šunų veislių sveikatingumą bei grynumą. Žinant dabartinę būklę galima koreguoti veisimo strategijas, jas labiau pritaikyti konkrečiai situacijai. Šio darbo tikslas - i̇vertinti šunų veisimo tikslus Lietuvoje, veisèjų taikomas skirtingas selekcijos ir reprodukcijos metodikas, gyvūnų atrankos veisimui kriterijus. Tam tikslui domėtasi veisèjų išsilavinimu, veislininkystejje naudojamais informacijos šaltiniais, veisimo motyvacija, tikslais ir strategijomis, taip pat nuomone apie modernių genetinių tyrimų svarbą šiuolaikinèje veislininkysteje. Tyrimo metodas - anoniminė anketinė apklausa internetu. Apibendrinus duomenis nustatyta, kad veisėjams trūksta viešai prieinamos informacijos šunų veisimo klausimais. Dauguma Lietuvos veisèjų (83,7\%) siekia pagerinti veislès eksterjerą, charakterio savybes bei šuniukų sveikatą, todèl dažniau pasirenkama linijinio veisimo strategija negu giminingas kryžminimas (30,2 \% ir 11,6 \% atitinkamai). Dauguma veisèjų pripažįsta genetinių tyrimų svarbą šunų veislininkystejje.

Raktažodžiai: veisëjai, veisimo tikslai, šunys, apklausa 